\title{
PENGEMBANGAN MODEL PRAKTIKUM UNTUK MENGEMBANGKAN KETERAMPILAN MAHASISWA CALON GURU DALAM PENILAIAN PEMBELAJARAN
}

\author{
Habibi Ratu Perwira Negara ${ }^{1} \&$ Susilahudin Putrawangsa ${ }^{2}$ \\ ${ }^{12}$ Universitas Islam Negeri Mataram, Mataram, Indonesia \\ 1habibiperwira@uinmataram.ac.id \& 2putrawangsa@uinmataram.ac.id
}

\begin{abstract}
Abstrak
Penelitian ini bertujuan untuk menemukan karakteristik dari model praktikum untuk mengembangkan keterampilan mahasiswa calon guru dalam melaksanakan penilaian pembelajaran. Penelitian ini adalah penelitian pengembangan yang mengacu pada model Design Research. Hasil penelitian ini menemukan bahwa model praktikum yang relevan untuk maksud tersebut adalah model praktikum yang mengembangkan keterampilan calon guru (selaku perancang instrumen penilaian) dalam (1) mengembangkan butir soal pilihan ganda, (2) mengembangkan butir soal uraian, dan (3) menganalisis kualitas dari butir soal tersebut baik secara kualitatif maupun kuantitatif. Ketiga kegiatan praktikum tersebut dirancang dalam suatu bentuk kegiatan pengembangan, yaitu pengembangan butir soal. Dalam rancangan kegiatan pengembangan tersebut, praktikan mengalami tiga tahapan kegiatan, yaitu (1) proses perencanaan (yaitu perumusan butir soal berdasarkan analisis kompetensi dan penyusunannya dalam suatu bentuk instrumen penilaian), (2) validasi instrumen penilaian baik secara kualitatif (validasi isi dan konstruksi) maupun secara kuantitatif (analisis butir), dan (3) perbaikan instrumen penilaian berdasarkan hasil validasi. Dalam model praktikum tersebut mahasiswa dilatih untuk menguasai: (1) keterampilan menerjemahkan kompetensi belajar ke dalam indikator belajar, (2) keterampilan merumuskan indikator soal berdasarkan indikator belajar, (3) keterampilan menyusun soal berdasarkan indikator soal beserta pedoman penskoran yang sesuai, dan (4) keterampilan menyajikan soal dalam suatu bentuk instrumen penilaian yang siap untuk digunakan sebagai alat penilaian. Pemahaman siswa tentang sasaran pembelajaran (kognitif, apektif, dan psikomotorik) dan pemahaman kebahasaan adalah dua faktor yang penting yang mempengaruhi kualitas butir instrumen penilaian yang dirumuskan oleh praktikan.
\end{abstract}

Kata Kunci: Pengembangan Model; Praktikum; Mahasiswa Calon Guru; Penilaian Pembelajaran; 


\section{PENDAHULUAN}

Istilah lain yang semakna dengan penilaian adalah assessmen (Reynolds, Livingstone \& Wilson, 2009), sedangkan assessmen didefinisikan sebagai seperangkat tindakan yang dilakukan secara sistematis untuk mengumpulkan informasi yang dapat dijadikan sebagai dasar untuk mengambil kesimpulan tentang karakteristik dari sekelompok orang atau objek (AERA, APA \& NCTM, 1999).

Sedangkan, istilah pembelajaran dipandang sebagai proses interaksi antara pengajar dan pembelajar di mana pembelajar dalam hal ini terlibat secara aktif dalam suatu usaha untuk mengembangkan pengetahuan, keterampilan, dan sikap positif tertentu dengan bantuan atau difasilitasi oleh pengajar (Suparman, 2014; Gagne, 1977; dan Joyce \& Weil 1980).

Dengan demikian, penilaian pembelajaran dapat dimaknai sebagai seperangkat tindakan yang dilakukan secara sistematis untuk mendapatkan informasi terkait karakteristik dari peserta didik, yang meliputi aspek pengetahuan, keterampilan, dan sikap positif sebagai dampak dari proses pembelajaran yang telah dilaluinya.

Keterampilan melakukan tindakan penilaian pembelajaran adalah salah satu kompetensi utama guru profesional yang termaktub dalam UndangUndang No. 14 Tahun 2005 tentang guru dan dosen. Keterampilan penilaian pembelajaran ini mencakup sejumlah keterampilan lainnya seperti keterampilan merumuskan instrumen penilaian, mengpenilaian kualitas instrumen penilaian, dan mengembangkan instrumen penilaian serta menyelenggarakan kegiatan penilaian (Budiyono, 2015; Reynolds dkk. 2009). Dalam keterampilan merumuskan instrumen penilaian, misalnya, seorang guru dituntut untuk memiliki tidak hanya pengetahuan tentang perumusan butir soal, melainkan juga keterampilan dalam merumuskan butir soal tersebut berdasarkan pertimbangan-pertimbangan pada analisis kompetensi pembelajaran. 
Dengan demikian, setiap mahasiswa calon guru dituntut untuk memiliki tidak hanya pengetahuan tentang penilaian pembelajaran melainkan juga terampil dalam melaksanakan dan mengembangkan instrumen penilaian pembelajaran.

Akan tetapi, hasil studi awal di Program Studi Pendidikan Matematika UIN Mataram menunjukkan bahwa perkuliahan penilaian pembelajaran untuk calon guru di perguruan tinggi tersebut lebih ditekankan pada penguasaan pengetahuan tentang penilaian pembelajaran, sedangkan penguasaan keterampilan melaksanakan kegiatan penilaian dan pengembangan instrumen penilaian belum menjadi prioritas yang utama. Akibatnya, sebagian besar mahasiswa calon guru hanya memiliki pemahaman tentang penilaian pembelajaran akan tetapi belum memiliki keterampilan untuk melaksanakannya apalagi untuk mengembangkannya. Padahal hal yang paling penting untuk dimiliki ketika guru di lapangan adalah keterampilan melaksanakan penilaian pembelajaran yang termasuk didalamnya adalah keterampilan menyusun instrumen penilaian yang berkualitas dan cara pengembangannya.

Berangkat dari masalah ini, penelitian ini bertujuan untuk mengembangkan model kegiatan praktikum penilaian pembelajaran untuk mahasiswa calon guru agar mereka tidak hanya memiliki pengetahuan tentang penilaian pembelajaran melainkan juga keterampilan melaksanakannya. Sehingga, rumusan masalah dari kegiatan penelitian ini adalah menjawab pertanyaan penelitian berikut ini: Apa karakteristik dari model praktikum penilaian pembelajaran matematika yang valid, efektif dan praktis untuk mengembangkan keterampilan mahasiswa calon guru dalam melaksanakan kegiatan penilaian pembelajaran?

\section{LANDASAN TEORI}

Istilah-istilah penting yang dijadikan sebagai rujukan oleh peneliti dalam penelitian ini dijabarkan pada bagian ini. 


\section{Pengembangan Model}

Kata pengembangan model tersusun atas dua kata, yaitu pengembangan dan model. Definisi secara teoritis untuk masing-masing kata dipaparkan pada paragrap di bawah ini.

Gravemeijer dan Cobb memaknai proses pengembangan sebagai serangkaian kegiatan yang sistematis dan iteratif guna menghasilkan suatu produk atau bentuk intervensi yang valid, efisien, dan praktis melalui serangkaian kegiatan eksperimen (Akker, Gravemeijer, McKenney \& Nieveen, 2006). Sedangkan Plomp \& Nieveen $(2010,2013)$ mengindikasikan proses pengembangan sebagai serangkain kegiatan yang sistematis yang teridiri atas kegiatan studi awal, perancangan, pengujian, evaluasi dan perbaikan yang dilakukan secara iteratif untuk menghasilkan suatu bentuk intervensi yang valid, efektif, dan efisien sebagai solusi terhadap suatu masalah yang kompleks atau untuk menemukan karakteristik dari intervensi tersebut beserta aspek-aspek lainnya yang terkait dengan pengembangannya. Sedangkan, McKenney \& Reeves (2012) menjabarkan proses pengembangan sebagai serangkaian kegiatan yang sistematis, iteratif, dan beorientasi teori untuk menghasilkan suatu bentuk intervensi yang berkontribusi pada pengembangan teori dan solusi atas masalah praktis. Tidak jauh berbeda dengan yang lainnya, Putrawangsa (2013), Putrawangsa dkk. (2013) dan Putrawangsa dkk. (2014) merumuskan kegiatan pengembangan sebagai suatu proses untuk menghasilkan suatu bentuk intervensi yang valid, praktis dan efektif yang dilakukan secara terstruktur, sistematis, dan iteratif serta berkontribusi secara teoritis dan praktis melalui siklus kegiatan perancangan, ujicoba rancangan, evaluasi dan perbaikan rancangan. Dengan demikian, berdasarkan Akker dkk. (2006), Plomp \& Nieveen (2010, 2013), McKenney \& Reeves, (2012) Putrawangsa (2013), Putrawangsa dkk. (2013) dan Putrawangsa dkk. (2014) dapat disimpulkan bahwa proses pengembangan merupakan suatu kegiatan 
yang terstruktur secara sistematis dan iteratif serta berdasarkan teori untuk menghasilkan suatu intervensi yang valid, efektif dan praktis sebagai solusi atas suatu masalah yang kompleks (kontribusi praktis) dan untuk menemukan karakteristik dari intervensi tersebut beserta aspek-aspek yang terkait dengan pengembangannya (kontribusi teoritis).

Sedangkan, istilah model memiliki berbagai makna terrgantung pada konteks penggunaannya. Hal inilah yang mengakibatkan sebagian besar orang memiliki berbagai defisini dan pandangan terhadap istilah model (Suparman, 2014). Misalnya, kata model pada model pembelajaran akan nampak berbeda dengan kata model pada model matematika atau model pada model peraga atau pada model konstruksi. Model juga sering bertukar makna dengan istilah lainnya yang serupa seperti metode, teknik, strategi, pendekatan, dan sebagainya.

Richey, Klein, dan Tracey (2011) mendefinisikan bahwa model mereperesentasikan realitas dengan menampilkan struktur dan tingkatan untuk menyatakan idelaisasi dan pandangan tentang suatu realitas. Sejalan dengan Richey, Klein, dan Tracey (2011), NSDL (2017) mengemukakan bahwa model merupakan suatu konstruksi manusia untuk membantu memudahkan untuk memahami sistem dan realita pada dunia nyata. Serupa dengan defisini sebelumnya, Suparman (2014) mendefinisikan model sebagai suatu representasi realitas yang menggambarkan struktur dan tatanan dari suatu konsep. Dalam hal ini, Harre (1960) dalam Suparman (2014) mengkatagorisasikan bentuk model dalam empat katagori, yaitu model fisik, model konseptual, model prosedural, dan model matematis. Model fisik merujuk kepada model yang berbentuk benda atau replika fisik atau visual dari sesuatu yang sesungguhnya. Sedangkan model konseptual merupakan deskripsi teoritis yang bersifat umum dan abstrak untuk menggambarkan pandangan tentang realita atau sintesis dari suatu penelitian yang didukung oleh data terbatas. Model prosedural adalah deskripsi umum 
yang menerangkan langkah-langkah dalam melakukan suatu tindakan. Terakhir, model matematis merupakan suatu bentuk model yang menjelaskan hubungan antara berbagai komponen atau faktor dalam suatu sistem. Dengan demikian, dapat disimpulkan bahwa model didefinisikan sebagai representasi yang menggambarkan sistem tatanan atau karakteristik dari suatu realita (dunia nyata) atau konsep (teori).

Berdasarkan uraian di atas, pengembangan model dapat didefinisikan sebagai suatu kegiatan yang terstruktur secara sistematis, iteratif dan berdasarkan teori untuk menghasilkan suatu representasi valid yang menggambarkan sistem tatanan atau karakteristik dari suatu realita (dunia nyata) atau konsep (teori) serta efektif dan praktis dalam penerapannya. Dalam penelitian ini, realita yang dimaskud merujuk pada model praktik penilaian pembelajaran sedang konsep merujuk karaktersitik konseptual yang mendasari kegiatan penilaian pembelajaran yang valid, efektif, dan praktis.

\section{Penilaian Pembelajaran}

Keterampilan melakukan penilaian pembelajaran merupakan salah satu bentuk kompetensi pedagogik guru profesional disamping keterampilan merencanakan dan melaksanakan pembelajaran. Untuk memahami makna dari penilaian pembelajaran, diperlukan pemahaman mengenai makna dari kata-kata pembentuk frase tersebut, yaitu penilaian dan pembelajaran.

Istilah penilaian adalah padanan istilah untuk istilah assessmen (Reynolds dkk., 2009). Sedangkan, assessmen didefinisikan sebagai seperangkat tindakan yang dilakukan secara sistematis untuk mengumpulkan informasi yang dapat dijadikan sebagai dasar untuk mengambil kesimpulan tentang karakteristik dari sekelompok orang atau objek (AERA dkk. 1999). Jadi, penilaian dapat dipandang sebagai tindakan menghimpun informasi tentang orang atau objek tertentu (program kegiatan, kejadian, dan sejenisnya) yang dilakukan secara 
sistematis untuk mendapatkan pemahaman mengenai karakteristik dari orang atau objek tersebut.

Sedangkan istilah pembelajaran dipandang sebagai proses interaksi antara pengajar dan pembelajar di mana pembelajar dalam hal ini terlibat secara aktif dalam suatu usaha untuk mengembangkan pengetahuan, keterampilan, dan sikap positif tertentu dengan bantuan atau difasilitasi oleh pengajar (Suparman, 2014; Joyce dan Weil, 1980). Dalam definisi di atas, sasaran pembelajaran tidak hanya pada aspek kognitif, melainkan juga pada aspek psikomotorik dan afektif.

Dengan demikian, penilaian pembelajaran dapat dimaknai sebagai seperangkat tindakan yang dilakukan secara sistematis untuk mendapatkan informasi terkait karakteristik dari peserta didik, yang meliputi aspek pengetahuan, keterampilan, dan sikap positif sebagai dampak dari proses pembelajaran yang telah dilaluinya.

Penilaian pembelajaran adalah penilaian terhadap proses mengajar. Secara sistematik, penilaian pembelajaran diarahkan pada komponenkomponen sistem pembelajaran yang mencakup komponen raw input, yakni prilaku awal (entry behavior) siswa, komponen input instrumental yakni kemampuan professional guru, komponen proses ialah prosedur pelaksanaan pembelajaranm komponen output ialah hasil pembelajaran yang menandai ketercapaian tujuan pembelajaran (Hamalik, 1995).

\section{Kompetensi Calon Guru}

Kompetensi pedagogik adalah kemampuan pemahaman terhadap peserta didik secara mendalam dan penyelenggaraan yang mendidik. Dalam Undang-Undang No, 14 Tahun 2005 tentang Guru dan Dosen dikemukakan kompetensi pedagogik merupakan kemampuan mengelola pembelajaran peserta didik. Salah satu kompetensi utama guru profesional yang termasuk kompetensi pedagogik guru adalah keterampilan melakukan tindakan penilaian pembelajaran (UU No. 14, 2005; Hasanah, Putrawangsa \& Ardi, 2017). 
Seorang calon guru harus memiliki kompetensi dalam mengpenilaian pembelajaran, ia harus mengetahui kapan dan bagaimana cara pelaksanaan penilaian pembelajaran tersebut. Adapun dalam membuat penilaian pembelajaran harus memperhatikan prosedur perencanaan, yang meliputi merumuskan tujuan penilaian, menyusun kisi-kisi, mengembangkan draf instrument, uji coba dan anlisis, merevisi dan menyusun instrument final. (2) Pelaksanaan penilaian yaitu prose lanjutan dari perencanaan, (3) pengelolaan data yaitu proses penskoran dari hasil pengukuran yang selanjutnya dilkuakn penilaian, (4) pelaporan hasil penilaian, dan (5) memanfaatkan hasil penilaian (Arifin, 2011).

Depdiknas (2004) mengemukakan kompetensi penilai belajar peserta didik, meliputi (1) mampu memilih sola berdasarkan tingkat kesukaran, (2) mampu memilih soal berdasarkan tingkat pembeda, (3) mampu memperbaiki soal yang tidak valid, (4) mampu memeriksa jawaban, (5) mampu mengklasifikasi hasil-hasil penilaian, (6) mampu mengolah dan menganalisis hasil penilaian, (7) mampu membuat interpretasi kecenderungan hasil penilaian, (8) mampu menentukan korelasi soal berdasarkan hasil penilaian, (9) mampu mengidentifikasi tingkat variasi hasil penilaian, (10) mampu menumpulkan hasil penilaian secara jelas dan logis, (11) mampu menyusun program tindak lanjut hasil penilaian, (12) mengklasifikasi kemampuan siswa, (13) mampu mengidentifikasi kebutuhan tindak lanjut hasil penialain, (14) mampu melaksanakan tindak lanjut, (15) mampu mengpenilaian hasil tindak lanjut, dan (16) mampu menganalisis hasil penilaian program tindak lanjut ahsil penilaian.

\section{METODE PENELITIAN}

Penelitian ini adalah sebuah penelitian pengembangan yang mengacu pada model peneltian pengembangan menurut Educational Design Research (Plomp \& Nieveen, 2010, 2013; McKenney \& Reeves, 2012; Akker dkk., 2006; 
Negara, H., R., P. \& Putrawangsa, S. (2017). PENGEMBANGAN MODEL PRAKTIKUM UNTUK MENGEMBANGKAN KETERAMPILAN MAHASISWA CALON GURU DALAM PENILAIAN PEMBELAJARAN . JURNAL TATSQIF, 15(2), Retrieved from: http://ejurnal.iainmataram.ac.id/index.php/tatsqif/article/view/1465.

Putrawangsa, 2013) yang secara umum terdiri atas tiga tahapan pengembangan, yaitu studi pendahuluan (preliminary reserach), perancangan dan pengembangan (protoyping), dan tinjauan pengembangan (retrospective analysis).

\section{Tahap studi pendahuluan (preliminary research)}

Kegiatan penelitian ini dimulai dengan sejumlah kegiatan studi awal sebagai dasar untuk menyusun kerangka konseptual model rancangan (design framework) seperti (1) rumusan masalah pengembangan, (2) tujuan pengembangan, (3) kriteria model rancangan, dan (4) proposisi rancangan (dalam hal ini hipotesis model kegiatan praktikum penilaian pembelajaran).

Untuk menyusun keempat kerangka konseptual rancangan tersebut, hal-hal yang dilakukan peneliti dalam tahap ini antara lain: analisis mendalam terhadap masalah penelitian, analisis konteks penelitian, tinjauan literatur, dan diskusi pakar.

\section{Tahap perancangan dan pengembangan model (prototyping)}

Mengacu pada keempat kerangka konseptual rancangan di atas, peneliti kemudian mengembangkan sebuah draf awal model praktikum penilaian pembelajaran (disebut Prototipe 1).

Pada tahap selanjutnya, dilakukan peninjuan isi (validitas isi) dan konstruksi (validitas konstruksi) terhadap prototipe 1. Validitas isi dalam hal meninjau apakah prototipe 1 sudah didasarkan atau relevan dengan kaedah keilmuan yang terkait (state-of-the-art knowledge). Sedangkan, validitas konstruksi merujuk pada apakah setiap komponen pembentuk rancangan saling berkaitan secara suportif antara yang satu dengan yang lainnya. Untuk melakukan kedua jenis validitas ini, peneliti melibatkan sejumlah pakar dengan cara diskusi panel. Hasil dari kegiatan ini dijadikan sebagai dasar untuk memperbaiki prototipe 1 yang hasil perbaikan tersebut menghasilkan prototipe 2 . Dalam hal ini, prototipe 2 dianggap valid karena telah melalui proses validasi isi dan konstruksi. 
Selanjutnya prototipe 2 diujicoba di lapangan guna mengukur efektivitas dan kepraktisannya. Efektivitas dalam hal ini merujuk pada apakah prototipe 2 menghasilkan hasil yang diharapkan seperti pada proposisi rancangan, atau dalam bahasa lain apakah proposisi rancangan terbukti di lapangan. Sedangkan kepraktisan rancangan merujuk pada apakah prototipe 2 dapat diterapkan dengan mudah oleh pengguna, yaitu dalam hal ini bagi dosen pembimbing kegiatan praktikum penilaian pembelajaran. Hasil analisis terhadap efektivitas dan keprakitasan prototipe 2 dijadikan sebagai dasar untuk merevisi prototipe 2. Revisi terhadap prototipe 2 kemudian menghasilkan prototipe 3. Dalam penelitian ini, prototipe 3 merujuk pada model praktikum penilaian pembelajaran yang telah mengalami proses validitas isi dan konstruksi, serta telah melalui tahapan ujicoba efektivitas dan kepraktisan. Prototipe 3 lebih lanjut dapat diujicoba kembali guna menghasilkan prototipe selanjutnya (prototipe 4, 5, dan seterusnya) yang lebih meyakinkan. Akan tetapi dalam penelitian ini, peneliti memaparkan hasil pengembangan model praktikum yang telah dikembangkan hingga prototipe 3.

Berdasarkan uraian di atas, secara umum kegiatan pada tahapan ini terdiri atas siklus kegiatan (1) perancangan model (designing), (2) pengujian model (experimenting), dan (3) perbaikan model (formative evaluation dan refining).

Ujicoba lapangan dalam penelitian ini dilakukan kepada sekitar 225 mahasiswa Program Studi Pendidikan Matematika Universitas Islam Negeri Mataram pada tahun pelajaran 2015/2016 dan 2016/2017.

\section{Tahap peninjauan pengembangan (retrospective analysis)}

Pada tahapan ini, peneliti meninjau kembali secara seksama, mendalam, dan terstruktur serta sistematis proses pengembangan yang telah dilakukan pada dua tahap sebelumnya yang bertujuan untuk merumuskan prinsip atau teori pengembangan. Dalam penelitian ini, 
prinsip pengembangan yang ingin diungkap adalah merumuskan karakteristik dari model praktikum penilaian pembelajaran matematika yang valid, efektif dan praktis untuk mengembangkan keterampilan mahasiswa calon guru dalam melaksanakan kegiatan penilaian pembelajaran.

\section{HASIL DAN PEMBAHASAN}

Secara umum, model praktikum penilaian pembelajaran dalam penelitian ini dirancang untuk membekali mahasiswa calon guru untuk memiliki pengetahuan dan keterampilan dalam melaksanakan kegiatan penilaian pembelajaran di sekolah, yaitu meliputi penguasaan pengetahuan dan keterampilan dalam merencanakan, menyusun, dan mengembangkan instrumen penilaian pembelajaran, serta mengorganisir dan melaksanakan kegiatan penilaian pembelajaran.

Bagian ini akan memaparkan historis proses pengembangan, yang dimulai dari pemaparan gambaran umum prototipe awal rancangan, kemudian dilanjutkan dengan pemaparan sejumlah hasil penilaian dari prototipe awal berdasarkan ujicoba prototipe awal. Prototipe awal kemudian direvisi dengan memperhatikan hasil penilaian. Model kegiatan praktikum yang telah direvisi (prototipe revisi) dijabarkan pada bagian berikutnya. Pada bagian akhir, hasil analisis retrospektif terhadap proses pengemabngan diuraikan.

\section{Prototipe Awal Model Praktikum Penilaian Pembelajaran}

Prototipe awal model praktikum dirancang untuk mengembangkan keterampilan praktikan dalam tiga aspek keterampilan penilaian pembelajaran, yaitu: (1) pengembangan indikator soal, (2) analisis secara kualitatif dan kuantitaif dari butir soal yang telah dikembangkan, (3) teknik penskoran dan penilaian terhadap butir soal yang telah dikembangkan. 
Pada kegiatan pengembangan indikator soal, dirancang 3 bentuk kegiatan, yaitu (1) praktikan melakukan analasis SK dan KD pada materi Matematika SMP atau SMA, (2) praktikan mengembangkan indikator pembelajaran dan indikator soal, (3) praktikan merumuskan butir soal Multiple Choice maupun soal essay berdasarkan indikator soal yang telah dikembangkan.

Pada kegiatan analisis secara kualitatif, dirancang 3 bentuk kegiatan, yaitu (1) praktikan melakukan validasi ke ahli, dalam hal ini dosen ataupun guru Matematika. Validasi dilakukan untuk mengetahui kualiatas butir soal yang telah dirumuskan baik secara isi, kontruk maupun bahasa. (2) praktikan melakukan revisi terhadap butir soal sesuai dengan saran yang diberikan oleh ahli. (3) praktikan melakukan uji coba butir soal yang telah direvisi.

Pada kegiatan analisis secara kuantitatif, dirancang 3 bentuk kegiatan, yaitu (1) praktikan melakukan analisis tingkat kesukaran, daya beda, fungsi pengecoh, validitas dan reabilitas baik pada soal Multiple Choice maupun soal essay. (2) praktikan melakukan revisi berdasarkan tingkat kesukaran, daya beda, fungsi pengecoh.

Pada kegiatan penskoran dan penilaian, dirancang 3 bentuk kegiatan, yaitu (1) praktikan memberikan skor terhadap butir soal Multiple Choice maupun soal essay berdasarkan hasil respon siswa. (2) praktikan melakukan penilaian berdasarkan hasil yang telah diperoleh.

\section{Penilaian Terhadap Prototipe Awal Model Praktikum}

Penilaian dilakukan berupa pemaparan kelemahan - kelemahan yang ditemukan pada kegiatan praktikum yang telah dilaksanakan. Adapun kelemahan yang ditemukan antara lain: (1) Penyusanan modul belum sistematis. Penyusanan yang dilakukan berupa teori pendukung dan mata acara/kegiatan praktikum dibuat menyatu, hal ini membuat praktikan menjadi kesulitan dalam menggunakannya, (2) kegiatan analisis butir soal secara kualitatif tidak optimal dilakukan. Hal ini 
didasarkan pada banyaknya butir soal secara komputasi menggunakan software ITEMAN dinyatakan bermasalah. Butir soal dianggap sukar, namun berdasarkan indikator soal, kualitas butir soal tersebut tidak tergolang dalam level sukar. Setelah dilakukan penelusuran yang mendalam, ditemukan bahwa bahasa atau redaksi soal yang disusun membuat siswa kesulitan dalam memahaminya. Temuan lain berupa, secara komputasi menggunakan software ITEMAN ditemukan banyak butir soal yang memiliki kunci jawaban lebih dari satu, hal ini mengindikasaikan fungsi pengecoh maupun daya beda butir soal tidak baik. Hasil temuan ini mengindikasiakan bahwa pada tahap analisis secara kualitatif belum dilaksanakan secara maksiamal. Selain dula kelemahan tersebut, ditemukan kelemahan lainnya, yaitu: (3) praktikan hanya fokus pada pengambangan soal Multiple Choice, sedangkan pengembangan soal bentuk essay tidak dilakukan, (4) pada kegiatan analisis secara kuantitatif, analisis hanya terbatas pada bagaimana melakukan perhitungan baik itu tingkat kesukaran, fungsi pengecoh, dan daya beda namun tidak mengungkap bagaimana dampak dari perhitungan tersebut. Pada kegiatan ini, praktikan seharusnya melakukan revisi terhadap butir soal yang dinyatakan tidak bagus, baik dilihat dari tingkat kesukaran, fungsi pengecoh dan daya beda. Sehingga hasil yang diperoleh adalah soal-soal yang valid, (5) Praktikan tidak melakukan penskoran dan penilaian dari hasil analisis yang telah dilakukan, sehingga tujuan akhir yang ingin dicapai mengenai penilaian hasil belajar tidak terpenuni.

Berdasarkan hasil penilaian di atas, prototipe model praktikum penilaian pembelajaran kemudian direvisi, yang kemudian dalam penelitian ini disebut sebagai prototipe akhir.

\section{Prototipe Akhir Model Praktikum Penilaian Pembelajaran}

Berdasarkan hasil penilaian, dilakukan perbaikan terhadap model praktikum penilaian pembelajaran. Perbaikan model praktikum 
dilakukan berupa (1) perbaikan sistematika penulisan modul, (2) proporsi antara pengembangan soal multiple choice dan essay dibuat sama, (3) melakukan analisis kualitas butir soal baik secara kualitatif dan kuantitatif, (4) melakukan kegiatan revisi butir soal berdasarkan analisis kualitataif dan kuantitatif, (5) praktikan melakukan penskoran dan penilaian terhadap butir soal.

Perbaikan terhadap sistematika penulisan modul dilakukan dengan membagi modul menjadi 4 bagian yang sebelumnya hanya 2 bagian. Pada Bagain pertama merupakan pendahuluan yang menjelaskan mengenai latar belakang, tujuan, sasaran, strategi pelaksanaan dan waktu pelaksanaan praktikum. Pada bagian kedua yang merupakan landasan teori yang berisi penjelasan teori tentang kisi-kisi, indikator soal, analisis butir soal secara kualitatif dan secara kuantitatif. Pada bagian ketiga merupakan pedoman acara praktikum. Pada bagain keempat berisi tentang penjelasan mengenai pelaporan dari kegaitan praktikum yang telah dilaksanakan. Pada tahap akhir ini mahasiwa melaporkan hasil soal-soal yang telah dikembangkan dan dinyatakkan valid dan reliable. Untuk selanjutnya dihimpun sebagai suatu kumpulan soal yang dijadikan Bank Soal.

Pada bagian ketiga merupakan pedoman acara praktikum. Praktikum dilaksanakan sebanyak 6 kali pertemuan, pertemuan merupakan pengembangan soal multiple Choice. Pada pertemuan ini praktikan melakukan analisis SK dan KD untuk dikembangkan menjadi indikator pembelajaran, indikator soal dan terakhir merumuskan butir soal. Selanjutnya, praktikan melakukan analisis secara kualitataif dengan melakukan validasi ke ahli mengenai validasi isi, kontruk dan bahasa. Praktikan memastikan bahwa kualitas butir soal yang telah dirumuskan valid dengan melakukan revisi sesuai dengan arahan dan saran yang diberikan oleh ahli. 
Pertemuan II adalah kegiatan pengembangan soal Essay. Pada kegaitan ini, tidak jauh beda dengan kegiatan pada pertemuan I. Praktikan menganalisis SK dan KD yang sama saat mengembangan soal multiple Choice, selanjutnya diturunkan menjadi indikator pembelajaran, indikator soal, merumuskan butir soal dan menyusun rubrik penilaian. Praktikan meminta pendapat ahli mengenai kevalidan isi, kontruk dan bahasa, serta melakukan revisi sesuai dengan arahan dan saran yang diberikan oleh ahli.

Pertemuan III adalah pengembangan soal multiple choice dan Essay. Pada kegiatan ini praktikan melakukan uji lapangan dengan mengujicobakan soal multiple choice maupun soal essay. Kegiatan ini untuk mengetahui respon siswa mengenai soal yang telah dikembangkan. Pada pertemuan IV, praktikan melakukan analisis soal multiple choice secara kuantitatif berdasarkan jawaban siswa pada pertemuan ke III. Analisis dilakukan menggunakan software ITEMAN, dimana hasil diperoleh berupa tingkat kesukaran, fungsi pengecoh dan daya beda soal. Hasil ini selanjutnya dijadikan dasar dalam meninjau kualitas butir soal yang telah dikembangkan. Pertemuan V adalah analisis soal essay secara kuantitatif. Analisis dilakukan berdasarkan rubrik penilain yang telah disusun untuk memperoleh informasi berupa tingkat kesukaran dan daya beda soal. Hasil akhir kegiatan ini, praktikan merevisi soal-soal yang dinyatakan kurang baik berdasarkan tingkat kesukaran, fungsi pengecoh dan daya beda soal.

\section{Analisis Retrospektif dari Proses Pengembangan}

Berdasarkan hasil penelitian ini, disimpulkan bahwa keterampilan dalam melaksanakan penilaian pembelajaran tidak dapat dipisahkan dari sejumlah keterampilan dasar yang membangunnya, yaitu: keterampilan menerjemahkan kompetensi belajar ke dalam indikator belajar, (2) keterampilan merumuskan indikator soal berdasarkan indikator belajar, (3) keterampilan menyusun soal berdasarkan indikator 
soal beserta pedoman penskoran yang sesuai, dan (4) keterampilan menyajikan soal dalam suatu bentuk instrumen penilaian yang siap untuk digunakan sebagai alat penilaian.

Selain keempat keterampilan tersebut, seorang perancang instrumen penilaian pembelajaran juga dituntut untuk memiliki pemahaman yang komprehensip terkait dengan sasaran pembelajaran, yaitu ranah kognitif, apektif, dan psikomotorik serta metode yang relevan untuk mengpenilaiannya. Hal ini diperlukan agar isntrumen penilaian yang dikembangkan dapat disesuaikan dengan sasaran pembelajaran yang ingin dipenilaian. Misalnya, instrumen penilaian berebntuk pilihan ganda akan lebih relevan digunakan untuk mengpenilaian ranah kognitif dari siswa, sedangkan instrumen penilaian berbentuk uraian lebih cocok digunakan untuk mengpenilaian ranah psikimotorik siswa.

Selain dua hal di atas, faktor bahasa adalah hal yang perlu menjadi perhatian. Terbatasnya kemampuan praktikan dalam hal kebahasaan mempengaruhi kualitas redaksi soal yang disusun. Hanya karena redaksi penyampaian yang kurang memenuhi standar ejaan bahasa yang benar, soal yang secara isi sudah baik menjadi kurang baik. Selain itu, kelemahan dalam bahasa mengakibatkan buruknya redaksi soal yang disusun oleh pembuat soal.

\section{KESIMPULAN}

Berdasarkan hasil penelitian, salah satu model praktikum yang relevan adalah model praktikum yang mengembangkan keterampilan calon guru (selaku perancang instrumen penilaian) dalam (1) mengembangkan butir soal pilihan ganda, (2) mengembangkan butir soal uraian, dan (3) menganalisis kualitas dari butir soal tersebut baik secara kualitatif maupun kuantitatif. Ketiga kegiatan praktikum tersebut dirancang dalam suatu bentuk kegiatan pengembangan, yaitu pengembangan butir soal. Dalam rancangan kegiatan pengembangan tersebut, praktikan akan mengalami 
Negara, H., R., P. \& Putrawangsa, S. (2017). PENGEMBANGAN MODEL PRAKTIKUM UNTUK MENGEMBANGKAN KETERAMPILAN MAHASISWA CALON GURU DALAM PENILAIAN PEMBELAJARAN . JURNAL TATSQIF, 15(2), Retrieved from: http://ejurnal.iainmataram.ac.id/index.php/tatsqif/article/view/1465.

sejumlah proses krusial yang terbagi dalam tiga tahapan kegiatan, yaitu (1) proses perencanaan (yaitu perumusan butir soal berdasarkan analisis kompetensi dan penyusunannya dalam suatu bentuk instrumen penilaian), (2) validasi instrumen penilaian baik secara kualitatif (validasi isi dan konstruksi) maupun secara kuantitatif (analisis butir), dan (3) perbaikan instrumen penilaian berdasarkan hasil validasi.

Dalam kegiatan pengembangan tersebut, perancang instrumen penilaian dilatih untuk menguasai: (1) keterampilan menerjemahkan kompetensi belajar ke dalam indikator belajar, (2) keterampilan merumuskan indikator soal berdasarkan indikator belajar, (3) keterampilan menyusun soal berdasarkan indikator soal beserta pedoman penskoran yang sesuai, dan (4) keterampilan menyajikan soal dalam suatu bentuk instrumen penilaian yang siap untuk digunakan sebagai alat penilaian.

Sebelum kegiatan pengembangan instrumen soal tersebut dilakukan, perancang perlu dibekali dengan pemahaman yang komprehensip terkait dengan sasaran pembelajaran, yaitu ranah kognitif, apektif, dan psikomotorik serta metode yang relevan untuk mengpenilaiannya. Hal ini diperlukan agar isntrumen penilaian yang dikembangkan dapat disesuaikan dengan sasaran pembelajaran yang ingin dipenilaian.

Selain itu, pengetahuan dan keterampilan kebahasaan adalah faktor yang penting bagi seorang perancang instrumen penilaian. Lemhanya kemampuan prancang dalam hal kebahasaan mempengaruhi kualitas redaksi soal yang disusun.

\section{DAFTAR PUSTAKA}

Akker, J. V., Gravemeijer, K., McKenney, S., \& Nieveen, N. (2006). Educational Design Research. London: Taylor \& Francis Ltd.

American Educational Research Association (AERA), American Psycological Association (APA), \& National Council on Measurement in Education (NCME). (1999). Standard for teacher competences in educational assessment of students. Washington, D.C.: American Federation of Teachers. 
Negara, H., R., P. \& Putrawangsa, S. (2017). PENGEMBANGAN MODEL PRAKTIKUM UNTUK MENGEMBANGKAN KETERAMPILAN MAHASISWA CALON GURU DALAM PENILAIAN PEMBELAJARAN . JURNAL TATSQIF, 15(2), Retrieved from: http://ejurnal.iainmataram.ac.id/index.php/tatsqif/article/view/1465.

Budiyono. (2015). Pengantar Penilaian Hasil Belajar. Kentingan: UNS Press.

Direktorat Tenaga Kependidikan Depdiknas. (2004), Standar kompetensi Guru. Jakarta : Depdiknas.

Hasanah, U., Putrawangsa, S., \& Ardi, R. (2017). PENILAIAN KUALITAS INSTRUMEN PENGUKURAN KINERJA TENAGA PENDIDIK. JURNAL TATSQIF, 15(1). Retrieved from http://ejurnal.iainmataram.ac.id/index.php/tatsqif/article/view/1310

Joyce, B. \& Weil, M. (1980). Model of Teaching. New Jersey: Prentice Hall.

McKenney, Susan, and Thomas C. Reeves (2012). Conducting Educational Design Research. Oxon: Routledge.

NSDL (2017) What is a Model? Diakses dari https://serc.carleton.edu/introgeo/models/WhatIsAModel.html pada tanggal 27 November 2017.

Oemar Hamalik. (1995). Kurikulum dan Pembelajaran (Cet-1). Jakarta: Penerbit Bumi Aksara.

Zainal Arifin. (2011). Penilaian Pembelajaran (Cet-3). Bandung: Penerbit Remaja Rosdakarya.

Plomp, Tjeerd, and Nienke Nieveen. (2010). An Introduction to Educational Design Research. Enschede: SLO-Netherlands Institute for Curriculum Development.

Plomp, Tjeerd, and Nienke Nieveen. (2013). An Introduction to Educational Design Research. Enschede: SLO-Netherlands Institute for Curriculum Development.

Putrawangsa, S. (2013). Educational Design Research: Developing Students" Understanding of The Multiplication Strategy in Area Measurement. Master Thesis www.fisme.science.uu.nl/en/impome/theses group 2012 /thesis Sis.pdf\&lc=en- Surabaya: Universitas Negeri Surabaya.

Putrawangsa, S., Lukito, A., Amin, S.M., dan Wijers, M. (2013) Educational Design Research: Developing Students' Understanding of Area as the Number of Measurement Units Covering a Surface. Dalam Zulkardi (Eds.) Proceeding The First South East Asia Design/Development Research (SEA-DR) International Conference (Hal. 416 - 426 eprints.unsri.ac.id/2451/). Palembang: Eprint Unsri

Putrawangsa, S., Wijers, W., Lukito, A., \& Amin, S.M. (2014) Educational Design Research: Developing Students' Understanding Of 
Measurement Units Of Area. Proceeding International Seminar on Innovation in Mathematics and Mathematics Education (Hal. 125 - 136 http://eprints.uny.ac.id/24250/1/E-17.pdf). Yogyakarta: Universitas Negeri Yogyakarta

Reynolds, C.R., Livingstone, R.B. \& Willson, V. (2009). Measurement and Assessment in Education (2 ${ }^{\text {nd }}$ Edition). New Jersey: Person.

Richey, Klein, dan Tracey. (2011). The instructional design knowledge base: theory, research, and practice. New York: Rautledge.

Suparman, M.A. (2014). Desain Instruksional Modern (Edisi Keempat). Jakarta: Penerbit Erlangga. 